\title{
Impact of solar heat enhanced by the use of black polypropylene sheets on the development of Callosobruchus maculatus Fabricius (Coleoptera: Chrysomelidae) eggs and germinabilty of cowpea seeds
}

\author{
F. A. Ajayi ${ }^{1}$ (1) E. Peter ${ }^{2}$ (D) E. Okrikata ${ }^{3}$ (I) R. A. L. Emmanuel ${ }^{1}$ - S. A. Dattijo ${ }^{4}$ - E. A Kayode ${ }^{1}$
}

Received: 16 October 2020 / Accepted: 4 February 2021 / Published online: 11 February 2021

(c) The Author(s) 2021

\begin{abstract}
Post-harvest losses caused by Callosobruchus maculatus is a major constraint to cowpea production and the improper use of synthetic insecticides by most farmers have resulted in environmental, health hazards, and development of insecticide resistance in insects. This study evaluates the efficacy of solar heat treatment using double-layered black polypropylene sheets in suppressing the development of the cowpea bruchid eggs and the effect of the heat absorbed on the germination potential of cowpea seeds. Five pairs of 2 - 3-day old adult C. maculatus were allowed to oviposit for ten days on $50 \mathrm{~g}$ cowpea seeds in a glass jar in the laboratory before exposure to $24,48,72$ and $96 \mathrm{~h}$ solar heat treatment regimes. Infested cowpea seeds but not exposed to solarization was set along with the treatments while uninfested cowpea seeds was also set along and used as part of the germinability test. The experiment was laid out in a completely randomized design and treatments were replicated four times. The results showed that there were no significant differences among the number of eggs laid by adult $C$. maculatus on the cowpea seeds before solar heat treatment. Solar heat treatment of the cowpea seed at $24 \mathrm{~h}$ achieved $100 \%$ egg mortality of $C$. maculatus thus preventing adult emergence. The effect of solarization on seed viability showed that there were no significant differences between the infested cowpea seeds exposed to different solar radiation regimes when compared to uninfested cowpea seeds - range; $74 \%-99 \%$ germination. The results showed that $24 \mathrm{~h}$ solar heat exposure of cowpea seeds in double-layered black polypropylene sheets could be the thermal death point of $C$. maculatus eggs on the seeds in the study area.
\end{abstract}

Keywords Solar heat $\cdot$ Black polypropylene $\cdot$ Callosobruchus maculatus $\cdot$ Cowpea seed $\cdot$ Germinability

\section{Introduction}

Cowpea Vigna unguiculata (L.) Walpers is an important legume in many developing countries (Adam and Baidoo 2008) which serves as a major food and animal feed

F. A. Ajayi

faajayi@nsuk.edu.ng

1 Faculty of Agriculture (Shabu-Lafia Campus), Nasarawa State University Keffi, P.M.B. 135, Lafia, Nasarawa State, Nigeria

2 Department of Agronomy, Faculty of Agriculture, Federal University Gashua, P.M.B. 1005, Gashua, Yobe State, Nigeria

3 Department of Biological Sciences, Federal University Wukari, Wukari, Taraba State, Nigeria

4 Department of Pest Management Technology, Audu Bako College of Agriculture, Dambatta, Kano State, Nigeria crop to many households. It accounts for about $60 \%$ of human dietary protein intake and provides a comparatively cheaper alternative to animal proteins in Nigeria (Dugje et al. 2009). The crop is an important protein source for vegetarians and also a cheap alternative to animal protein. However, many constraints, such as diseases, insect pests, and the limited use of fertilizers, and irrigation inputs pose a threat to its production and storage in Nigeria and other developing countries (Brisibe et al. 2011).

In storage, the cowpea weevil, Callosobruchus maculatus (Fab.) is the major cause of post-harvest losses to cowpea. It begins its infestation from the field and into storage (Peter and Sule 2019a). Post-harvest losses of up to $90 \%$ due to heavy infestation by $C$. maculatus on stored cowpea have been reported (Radha and Susheela 2014). The infested cowpea seeds become less desirable for human consumption and most times are not used for 
seeds and market purposes as a result of insect eggs and exit holes appearance on seeds (Lale and Ajayi 2001).

The use of chemical insecticides and fumigants are the major control measures adopted by majority of farming households in Nigeria and other developing nations. While these chemical control measures are largely effective, their improper use has attendant effects such as environmental pollution, human health problems, and development of insecticide resistance in insects (Okrikata and Oruonye 2013). Also due to the low scale production practices and high poverty levels of most farmers in sub-Saharan Africa and other countries in the tropics, they opt to rely on indigenous traditional control measures to preserve their stored agricultural produce and products (Medugu et al. 2020).

In sub-Saharan Africa, many farming communities use solar radiation to suppress pest damage in their stored cowpea seeds (Peter and Sule 2019b). They sun-dry their produce/products by the road side, on mats, flat stones etc. Exposing the insects to solar radiation tends to kill the insects as they have been shown to be sensitive to heat and high temperatures (Peter and Sule 2019b). However, exposing cowpea seeds to solar radiation in the open is less efficient as a result of constant air current which may fluctuate the amount of heat absorbed by the seeds rendering it less fatal to the insects. Exposing grains in polymers as solar heat collectors have been shown to be capable of raising the temperature of seeds to a lethal level for the weevils (Murdock et al. 2003; Hansen et al. 2011). Thus, this study was carried out to evaluate the efficacy of solar heat using double-layered black polypropylene sheets on the development of the cowpea bruchid eggs and the effect of the heat absorbed on the germinability of cowpea seeds.

\section{Materials and methods}

\section{Experimental site}

The experiment was carried out in the laboratory and surrounding area of Faculty of Agriculture (Shabu-Lafia Campus), Nasarawa State University Keffi, Nasarawa State, Nigeria. Lafia is situated on Latitude $08.33^{\circ} \mathrm{N}$ and Longitude $08.33^{\circ}$ E (Lyam 2000).

\section{Insect culture and rearing}

Cowpea seeds infested with C. maculatus were obtained from a local market in Lafia, Nasarawa State. From this stock, new generations were raised in four Kilner jars under ambient temperature and relative humidity in the laboratory.

\section{Cowpea seed treatment and maintenance}

Five kilogramme of cowpea seed (local variety Kananado) was purchased from a local market in Lafia, Nasarawa State. Pristine cowpea seeds were picked from the lot. The cowpea seeds were transferred into a double-layered polythene bag and the opening was held with a tight rubber band to prevent any water seepage in the freezer, and the polythene bag containing the seed was kept at $-18^{\circ} \mathrm{C}$ inside a freezer for five days. After 5 days of cold treatment, the seeds were placed and spread on polythene sheet on a laboratory bench and covered with screen gauze held in place at the edges with heavy stones, so that the seeds can equilibrate to atmospheric conditions for three days. Thereafter, the cowpea seeds were packed into disinfested Kilner jars and kept on the laboratory bench until ready for use.

\section{Infestation of cowpea seeds with the cowpea seed beetles for experimental study}

Fifty grammes of cowpea seeds each were weighed into twenty glass jars with a lid cover. The glass jars containing cowpea seeds were thereafter infested with $2-3$ days old, ten cowpea bruchids comprising of five females and five males each and were allowed to mate and oviposit for a period of ten days on the cowpea seeds. Thereafter, dead and live insects in the glass jars were removed; while the number of eggs laid on the cowpea seeds were counted and recorded.

\section{Solar radiation technique and exposure}

Exposure of infested seeds to solar heat energy was conducted following the procedure described by Mekasha et al. (2006) with some modifications. A $30 \times 30 \mathrm{~cm}$ black polypropylene $(0.05 \mu \mathrm{m}$ thickness) sheet was laid out on a raised platform. Infested seeds (50 g) carrying cowpea bruchid eggs were spread thinly on the black polypropylene sheets. Another black polypropylene sheet measuring $35 \times 35 \mathrm{~cm}$ in size was overlaid on the 1 st polypropylene sheet (which was carrying the infested cowpea seeds) so that the edges of the 2 nd wider sheet wrapped up the edges of the 1st smaller sheet like a top cover.

The black polypropylene sheets bearing the infested cowpea seeds were exposed to solar heat treatment for $24,48,72$, and $96 \mathrm{~h}$ (h.), respectively. A control (0 h 
exposure) was laid out in the laboratory and not exposed to solar radiation. The study was carried out in a completely randomized design and the treatments replicated four times. The exposure period was carried out from sunrise to sunset for each day and the treatment was removed and kept in the laboratory throughout the night and brought out the next day for the solarization treatment to continue until the individual exposure period (hours) were met.

At the end of each exposure period, the infested cowpea seeds were removed from the polypropylene sheets and returned into the glass jars and laid on the laboratory bench and checked daily until adult emergence. At the 10th day post-treatment, the number of adults that emerged was recorded (the unhatched eggs were considered dead) and this was used to compute egg mortality (\%). The appearance of the eggs as described by Marcileyne et al. (2004) was used in determining whether or not an egg hatched. The setup was then keenly observed for progeny emergence and counting was done for each treatment for 2 weeks starting from the day of the 1 st adult emergence. This data along with the number of hatched eggs from each treatment was used to compute adult emergence (\%) using the formula described by Yussef et al. (2007):

$$
\text { Adult emergence }(\%)=\frac{\text { Number of adult emergence }}{\text { Number of eggs laid }} \times 100
$$

\section{Effect of solarization on the seed germination}

Fifteen seeds from each of the cowpea seeds exposed to solar heat treatment regimes [0, 24, 48, 72, and $96 \mathrm{~h}$ (h.)] were placed separately on moisten Petri dishes $(9 \mathrm{~cm}$ diameter) each containing three layers of Whatman's filter paper for the germinability test. The Petri dishes were then covered and laid on laboratory benches. Another batch of non-infested cowpea seeds (15 seeds) which were not exposed to heat treatment were also set to determine the effect of solar heat treatment on the germination of cowpea seeds. Each treatment was replicated four times. Continuous watering of the seeds was done with distilled water from a wash bottle. Germination count was taken on the 5th day post-sowing. Germination percentage of the cowpea seeds were calculated using the formula described by Olisa et al. (2010):

Germination $(\%)=\frac{\text { Number of emerged seedlings }}{\text { Number of seeds assessed }} \times 100$

\section{Data collection and analysis}

Data in percentages were arcsine transformed before variance analysis. Significantly different treatment means
Table 1 Mean oviposition of cowpea bruchids, C. maculatus (F.) exposed to cowpea seeds Vigna unguiculata (var. Kananado) before solar heat treatment

\begin{tabular}{ll}
\hline Exposure period $(\mathrm{h})$ & $\begin{array}{l}\text { Mean number of eggs laid } \\
\text { by } 5 \text { female cowpea bruchids }\end{array}$ \\
\hline 24 & 413.75 \\
48 & 572.00 \\
72 & 576.75 \\
96 & 526.25 \\
0 (Control) & 556.50 \\
SED & 137.26 \\
LSD $(0.05)$ & 179.40 \\
\hline
\end{tabular}

were separated by Least Significant Difference (LSD) at $\mathrm{P} \leq 0.05$ probability value using GENSTAT software, version 13. The relationships between cowpea bruchids' egg mortality, adult emergence of cowpea bruchids, cowpea seed germinability and the solar heat exposure time of infested cowpea seeds were determined by correlation and linear regression using IBM SPSS Statistics version 23.0

\section{Results}

Table 1 shows the mean number of eggs laid by each batch of 5 female cowpea bruchids on $50 \mathrm{~g}$ of cowpea seeds before exposure to the various solar heat treatment regimes. The results indicate that on the average, each female cowpea bruchid lays 100 eggs on the cowpea seeds. The statistical analysis also shows that, the observed differences in the number of eggs laid by the cowpea bruchids on the cowpea seeds were due to random variation $(\mathrm{P}>0.05)$.

Table 2 shows that egg mortality which was recorded as a function of the inability of the eggs laid to hatch was $100 \%$ on seeds exposed to $24 \mathrm{~h}$ solar heat treatment and was statistically at par with $48 \mathrm{~h}(99.04 \%), 72 \mathrm{~h}(96.50 \%)$, and $96 \mathrm{~h}(99.71 \%)$ treatments. Cowpea seeds that were not

Table 2 Percentage mean egg mortality of cowpea bruchids, $C$. maculatus (F.) on the cowpea seeds Vigna unguiculata (var. Kananado) exposed to solar heat treatments

\begin{tabular}{lc}
\hline Exposure period $(\mathrm{h})$ & Mean egg mortality $(\%)$ \\
\hline 24 & $100.0(90.00)^{*}$ \\
48 & $99.04(84.39)$ \\
72 & $96.50(79.16)$ \\
96 & $99.71(86.92)$ \\
0 (Control) & $12.40(20.55)$ \\
SED & 3.79 \\
LSD $(0.05)$ & 8.08 \\
\hline
\end{tabular}

*Figures in parentheses are arcsine values to which SED and LSD are applicable. 
Table 3 Percentage mean adult emergence of cowpea weevils $C$. maculatus (F.) from cowpea seeds (var. Kananado) exposed to solar heat treatments

\begin{tabular}{lc}
\hline Exposure period $(\mathrm{h})$ & $\begin{array}{l}\text { Mean adult } \\
\text { emergence } \\
(\%)\end{array}$ \\
\hline 24 & $0.00(0.00)^{*}$ \\
48 & $0.69(4.77)$ \\
72 & $3.50(10.84)$ \\
96 & $0.58(4.39)$ \\
0 (Control) & $87.60(69.44)$ \\
SED & 4.02 \\
LSD $(0.05)$ & 8.57 \\
\hline
\end{tabular}

*Figures in parentheses are arcsine values to which SED and LSD are applicable.

exposed to solar heat treatment (control) had significantly $(\mathrm{P}<0.05)$ the least egg mortality $(12.40 \%)$.

Table 3 showed that the exposure of infested cowpea seeds to solar heat treatments significantly $(\mathrm{p}<0.05)$ suppressed adult emergence. Adult emergence $(\%)$ was based on number of eggs that hatched and since exposure of infested cowpea seeds to $24 \mathrm{~h}$ solar heat treatment resulted to $100 \%$ mortality of cowpea bruchid eggs (Table 2), it is not surprising that no adult emerged from same treatment. However, the aforementioned treatment was statistically comparable to 48,72 and $96 \mathrm{~h}$ solar heat exposures which had $0.69 \%, 3.50 \%$ and $0.58 \%$ adult emergence, respectively. Cowpea seeds not exposed to solar heat treatment (control) had significantly $(\mathrm{p}<0.05)$ the highest proportion of adult bruchid emergence $(87.60 \%)$.

Table 4 shows that solar thermal treatment had insignificant negative impact on germination of cowpea seeds. Statistical analysis showed that differences in germination (\%) among infested seeds exposed to solar heat treatments were due to random variation and were statistically comparable with the germination (\%) of seeds

Table 4 Effect of solar heat treatments germination (\%) of cowpea seeds Vigna unguiculata (var. Kananado) infested with the cowpea weevils C. maculatus (F.)

\begin{tabular}{lc}
\hline Exposure period $(\mathrm{h})$ & Mean germination $(\%)$ \\
\hline 24 & $86.10(68.07)^{*}$ \\
48 & $73.90(59.30)$ \\
72 & $90.20(71.81)$ \\
96 & $74.20(59.46)$ \\
0 (Infested Control) & $2.50(9.09)$ \\
0 (Uninfested Control) & $99.58(86.25)$ \\
SED & 7.01 \\
LSD (0.05) & 25.73 \\
\hline
\end{tabular}

*Figures in parentheses are arcsine values to which SED and LSD are applicable. that were both uninfested and not exposed to solar heat treatment. However, infested seeds that were not thermally treated had the least germination $(2.50 \%)$ which differ significantly $(\mathrm{p}<0.05)$ from the others.

Table 5 shows that while solar heat exposure time of infested cowpea seeds positively correlated with $\%$ egg mortality $(\mathrm{r}=0.70)$ and germination $(\%)$ of cowpea seeds $(r=0.65)$, the relationship was negative with $\%$ adult emergence $(r=0.69)$. All relationships were however insignificant ( $\mathrm{p}>0.05$ ) with low $\mathrm{R}^{2}$ values; $49.0 \%, 42.2 \%$ and $48.2 \%$, respectively.

\section{Discussion}

C. maculatus females have been reported to be capable of laying about 70 eggs individually (Fatemeh et al. 2009). The test insects used for this study laid an average of 100 eggs. This wide margin from the documented average (70 eggs/ female) may be attributed to a development or introduction of a new cowpea bruchid biotype - a phenomenon that has been well observed among stored-product pests (Fox et al. 2010). This has obviously thrown up a fresh facet for further studies in the study area. Overall, we observed some sort of increase in mortality of cowpea bruchid eggs and decrease in adult emergence with an increase in exposure time of solar heat treatment as indicated by the correlation and regression analyses. This is in consonance with earlier reports by Lale and Ajayi (2001) and Lale and Vidal (2003) who studied the effect of solarization on egg mortality and progeny emergence of $C$. maculatus and showed that; solar heat treatment of cowpea seeds can adequately control infestation by cowpea seed bruchids. It has been shown that exposing infested cowpea grains to a temperature of $57^{\circ} \mathrm{C}$ for $1 \mathrm{~h}$ in an oven kills all the immature stages (eggs, larvae and pupae) of C. maculatus within the seeds - this temperature per exposure time was thus reported as the thermal death point of $C$. maculatus (Murdock and Shade 1991).

Due to abundant sunshine, farmers in the tropics sundry their harvested grains on flat stones, mats or by the road side. Aside reducing the moisture content of the grains, this action is traditionally believed to suppress insect population before storage - the risk of pathogens easily contacting the grains on using these methods cannot be ruled out. The black polypropylene sheets used in wrapping the seeds before sun heating in the current study can be adjudged safer and yet effective in accumulating solar heat leading to higher mortality of the immature stages of the insect pests than when left to ambient temperature and other physical factors. The significantly high mortality of eggs and fewer (if any) adult emergence recorded in the current study is indicative of the suppressive effects of the heat treatments on immature stages 
Table 5 Correlation and linear regression analysis between cowpea weevil egg mortality, cowpea bruchid adult emergence, cowpea seed germinability and solar heat exposure time of bruchids infested cowpea seeds

\begin{tabular}{llll}
\hline Variable & $\begin{array}{l}\text { Correlation Coef- } \\
\text { ficient (r) }\end{array}$ & Regression equation & $\begin{array}{l}\text { Coefficient of } \\
\text { determination }\left(\mathrm{R}^{2}\right)\end{array}$ \\
\hline Egg mortality (\%) x Exposure time (h) & $0.700^{\mathrm{ns}}$ & $\mathrm{Y}=47.306+0.713 \mathrm{x}$ & 0.490 \\
Cowpea weevil adult emergence (\%) x Exposure time (h) & $-0.697^{\mathrm{ns}}$ & $\mathrm{Y}=52.58-0.711 \mathrm{x}$ & 0.482 \\
Cowpea seed germinability (\%) x Exposure time (h) & $0.650^{\mathrm{ns}}$ & $\mathrm{Y}=35.880+0.615 \mathrm{x}$ & 0.422 \\
\hline
\end{tabular}

ns - not significantly different $(p>0.05)$.

of cowpea weevils. This thus corroborates the findings of Peter and Sule (2019a) who showed that cowpea bruchids infesting cowpea seeds exposed to solar radiation in polypropylene sheets had lesser progeny development than the control.

The high egg mortality and less adult emergence (which apparently can be linked to the mortality or incapacitation of the occluded immature stages) observed in the current study could be attributed to the inability of $C$. maculatus life stages to thermoregulate as opined by Murdock and Shade (1991). Early detection and management of pests is a key component of integrated pest management strategies. That the eggs were exposed to solar heat treatment soon after oviposition/infestation and high levels of control were achieved as a result of the solar heat treatments indicates that this technique has the potential of curbing pest outbreak in the store as suggested by Maina and Lale (2004).

While some studies showed that solar heat treated seeds (depending on exposure duration) had higher germination than the untreated - unheated (Maina and Lale 2004; Fawki et al. 2014), others observed the reverse (Seidu et al. 2010). The current study shows that the solar heat treatment did not significantly suppress the germination potential of the cowpea seeds buttressing the report of Murdock et al. (2003) who showed that oven heating cowpea seeds at $80{ }^{\circ} \mathrm{C}$ for $6 \mathrm{~h}$ did not adversely affect germination. Similar result was also published by Peter and Sule (2019a) who showed that exposing cowpea seeds using polymer sheets to solar radiation did not drastically affect the germinability of the seeds. However, utmost care and good judgement must be taken if the seeds are primarily preserved for sowing and this is because the present study showed that the cowpea variety used had $99 \%$ germination potential while those thermally treated recorded $73 \%-90 \%$. However, that cowpea seeds are largely able to tolerate heat treatments may be attributed to its evolution in the semi-arid region with its characteristic higher temperatures.

In their review, Hansen et al. (2011) highlighted the efficiency of thermal treatments (solar heat treatment inclusive) in managing different stored-product pests. They also outlined the technological advances (such as the use of solar dryers, plastic solar heaters etc.) made, and some of which are expensive or difficult to adopt by illiterate and resource poor farmers, particularly, in the developing nations. The current technique however is simple and does not have these drawbacks, particularly in the tropics, as sunlight is abundant and the polypropylene sheets are readily available in the local markets.

\section{Conclusion and recommendation}

This study highlights the potential of solarization to effectively suppress the spread of $C$. maculatus on cowpea seeds during storage. The results showed that solarization at different regimes evaluated significantly suppressed the amount of the pests' eggs that hatched and adults that emerged without adversely affecting seed germination. Overall, the findings suggest that with the use of doubled layer polypropylene sheet, the thermal death point of $C$. maculatus in the study area could be pegged at $24 \mathrm{~h}$ exposure of infested cowpea seeds as $100 \%$ egg mortality was achieved without significantly suppressing germination potential of cowpea seeds. Therefore, considering the ease, safety, and affordability of this solar technique, particularly in the tropical developing nations, there is a need for its adoption for the management of $C$. maculatus on cowpea seeds.

\section{Declarations}

Conflict of interest The authors declare that they have no conflict of interest.

Open Access This article is licensed under a Creative Commons Attribution 4.0 International License, which permits use, sharing, adaptation, distribution and reproduction in any medium or format, as long as you give appropriate credit to the original author(s) and the source, provide a link to the Creative Commons licence, and indicate if changes were made. The images or other third party material in this article are included in the article's Creative Commons licence, unless indicated otherwise in a credit line to the material. If material is not included in the article's Creative Commons licence and your intended use is not permitted by statutory regulation or exceeds the permitted use, you will need to obtain permission directly from the copyright holder. To view a copy of this licence, visit http://creativecommons.org/licenses/by/4.0/. 


\section{References}

Adam JI and Baidoo PK (2008) Susceptibility of Five Cowpea (Vigna unguiculata) Varieties Attacked by Callosobruchus maculatus (Fab.) (Coleoptera: Bruchidae). J Ghana Scie Assoc 8(2):85-92. https://doi.org/10.4314/jgsa.v10i2.18044

Brisibe EA, Adugbo SE, Ekanem U, Brisibe F, Figueira GM (2011) Controlling Bruchid Pests of Stored Cowpea Seeds with Dried Leaves of Artemisia annua and two other Common Botanicals. Afr J Biotechnol 10(47):9586-9592. https://doi.org/10.5897/AJB10.2336

Dugje IY, Omoigui LO, Ekeleme F, Kamara AY and Ajeigbe H (2009) Farmers' Guide to Cowpea Production in West Africa. IITA, Ibadan, Nigeria, 20 pp. https://doi.org/10.13140/2.1.1597.5361

Fatemeh K, Ali AT, Yaghoub F and Samira F (2009) A Comparative Study on the Effect of Four Leguminous Species on Biological and Population Growth Parameters of Callosobruchus maculatus (F.) (Col.: Bruchidae). Adv Environ Biol 3(3):226-232

Fawki S, Abdel Fattah HM, Hussein MA, Ibrahim MM, Soliman AK and Salem DAM (2014) The Use of Solar Energy and Citrus Peel Powder to Control Cowpea Beetle Callosobruchus maculatus (F.) (Coleoptera: Chrysomelidae). 11th International Working Conference on Stored Product Protection. pp. 1022 - 1033. https:// doi.org/10.14455/DOA.res.2014.168

Fox CW, Bush ML, Messina FJ (2010) Biotypes of the Seed Beetle Callosobruchus maculatus have Differing Effects on the Germination and Growth of their Legume Hosts. Agric Forest Entomol 12:353362. https://doi.org/10.1111/j.1461-9563.2010.00484x

Hansen JD, Johnson JA, Winter DA (2011) History and Use of Heat in Pest Control: A Review. Int J Pest Manag 57(4):267-289. https:// doi.org/10.1080/09670874.2011.590241

Lale NES and Ajayi FA (2001) Suppression of Development of Callosobruchus maculatus (F.) (Coleoptera: Bruchidae) in Bambara Groundnut Seeds Exposed to Solar Heat in the Nigerian Savanna. J Pest Scie 74:133-137. https://doi.org/10.1046/j.1439-0280.2001.

Lale NES, Vidal S (2003) Simulation Studies on the Effects of Solar Heat on Egg-Laying, Development and Survival of Callosobruchus maculatus (F.) and Callosobruchus subinnotatus (Pic.) in Stored Bambara Groundnut Vigna subterranean (L.) Verdcourt. J Stored Prod Res 39:447-458. https://doi.org/10.1016/S0022474X(01)00034-0

Lyam A (2000) Nasarawa State. In: Mamman AH, Oyebanji JO and Peters SW (Eds.) Nigeria, A People United, A Future Assured Survey of States. Millennium Edition. Vol. 2. Gadammo Press. $383-392 \mathrm{pp}$.

Maina YT and Lale NES (2004) Integrated Management of Callosobruchus maculatus (F) Infesting Cowpea Seeds in Storage Using Varietal Resistance, Application of Neem (Azadirachta indica A. Juss) Seed Oil and Solar Heat. Int J Agric Biology 6(3):440-446

Marcileyne PLD, Jose VD, Reginaldo B and Jorge BT (2004) Alternation of cowpea Genotypes affects the Biology of Callosobruchus maculatus (Fabr.) (Coleoptera: Bruchidae). Scie Agric 61(1):27-31

Medugu MA, Okrikata E, Dunuwel DM (2020) Management of Sitophilus zeamais Motschulsky (Coleoptera: Curculionidae) using Nigerian Raw Diatomite. J App Scie Environ Manag 24(9):16631669. https://doi.org/10.4314/jasem.v24i9.26

Mekasha C, Dzolkifli O, Yusuf S, Rita M, Noorma O (2006) Short Communication-Developmental of Efficient Solar Heaters for Storage Insect Pest Management. Afr Crop Sci J 14(3):253-261

Murdock LL, Seck D, Ntoukamm G, Kitick L, Shade RE (2003) Preservation of Cowpea Grain in sub-Saharan Africa-bean/ cowpea CRSP contributions. Field Crop Res 2:169-178

Murdock LL, Shade RE (1991) Eradication of Cowpea Weevil (Coleoptera: Bruchidae) in Cowpeas by Solar Heating. Am Entomol 37:228-231. https://doi.org/10.1093/ae/37.4.228

Olisa BS, Ajayi SR and Akande SR (2010) Physiological Quality of Seeds of Promising African Yam Bean (Sphenomstylis stenocarpa. (Hoechst. Ex A. Rich) Harms) and Pigeon pea (Cajanus cajan L. Mill sp.) Landraces. Res J Seed Sci 3(2):93-101. https://doi. org/10.3923/rjss.2010.93.101

Okrikata E, Oruonye ED (2013) The Potential of Neem Based Pesticides in Integrated Pest Management in Nigeria: Aspects for More Scientific Investigation. Asian J Biol Life Sci 2(2):96-99

Peter E and Sule H (2019a) Efficacy of Solar Heat Using Polypropylene Sheets to Manage Callosobruchus maculatus (Fab.) Infesting Stored Cowpea. Asian J Biol Sci 12(3):404-411. https://doi. org/10.3923/ajbs.404.411

Peter E and Sule H (2019b) Potentials of Polypropylene Sheets in Trapping Solar Heat for the Management of Callosobruchus maculatus (Fab.) Infestation. J App Sci 19(4):349-354. https:// doi.org/10.3923/jas.2019

Radha R, Susheela P (2014) Efficacy of Plant Extracts on the Toxicity, Ovipositional Deterrence and Damage Assessment of the Cowpea weevil, Callosobruchus maculatus (Coleoptera: Bruchidae). J Entomol Zool Stud 2:16-20

Seidu JM, Mensah GWK, Zah VK, Dankwah SAA, Kwenin WKJ, Mahama AA (2010) The Use of Solar Dryers to Control Insect Infestation in Stored Grains in Ghana. Int J Biol Chem Sci 4(6):2397-2408

Yussef FBB, Thalles BG, Eder AF, Helano LL, Jose NSB, Manoel A, Mary ASL (2007) Insecticidal Activity of 2-tridecanone against the Cowpea weevil, Callosobruchus maculatus (Coleoptera: Bruchidae). Anais de Academia Brasileira de Ciencias 79(1):35-39 